\title{
How to win friends and influence people: climate scientists' perspectives on their relationship with and influence on government officials
}

\author{
JAMES W. STOUTENBOROUGH \\ Department of Political Science, Idabo State University, USA \\ E-mail: james.stoutenborough@isu.edu \\ REBECCA BROMLEY-TRUJILLO \\ Martin School of Public Policy and Administration, University of Kentucky, USA \\ E-mail: becky.bromley-trujillo@uky.edu \\ ARNOLD VEDLITZ \\ The Bush School of Government and Public Service, Texas A \\ E-mail: avedlitz@tamu.edu
}

\begin{abstract}
The use of scientific information in the policy-making process is prevalent in today's society, and political figures frequently consult scientists and experts when considering complex issues like climate change. While policy process literature concerning agenda setting and policy networks, such as epistemic communities and advocacy coalitions, considers the role of scientists in policymaking, very little work has provided insight into the relative influence and perceived relationships between scientists and policymakers. The ability of scientists and policymakers to work together has important implications for policy outcomes. We explore individual scientist's perceptions of the collective influence the scientific community has on policymaking, in addition to perceptions of relationships between scientists and policymakers. We suggest that a number of factors are relevant including trust, contact, attitudes, specialisation and demographics. Our findings indicate that, from scientists' perspectives, contact with policymakers, trust and attitudes about climate change play a significant role in shaping their relationship with policymakers.
\end{abstract}

Key words: climate change, policymakers, public policy, scientists' influence

\section{Introduction}

The complexity of modern-day issues leads to a particular need for the use of scientific information in the policy-making process. Political figures often 
turn to scientists and other experts to help elucidate and frame problems and solutions, especially when considering complex issues, such as climate change. This is indicated in literature on epistemic communities and advocacy coalition frameworks (ACFs) where scientists are identified as critical players in policy change (Haas 1992a; Weible et al. 2011).

The policy process includes a variety of access points at which scientists can play integral roles. As public policy makes its way through the policy cycle, moving through agenda setting, formulation, adoption, implementation and evaluation, scientists participate in nuanced ways. Scientists can bring items to governmental agendas by announcing new research findings, providing information noting a policy problem, or through efforts emphasising scientific consensus on pending policy issues. Scientists may also provide information that aids policymakers in the selection of policy instruments as policy is formulated (Turnhout et al. 2008). The ACF specifically identifies scientists as individuals who play a key role as policy brokers and as providers of information that may gradually adjust others' belief systems and that can be used by competing advocacy coalitions during the decision-making and implementation stages of the policy process (Sabatier and Zafonte 2001; Weible 2008). Research also indicates that scientists may go so far as to actively participate in the implementation of public policy, providing direct guidance using their expertise (Arvai et al. 2006; Turnhout et al. 2008).

While there are roles for scientists throughout the policy process, our work emphasises scientists' views of how they collectively influence agenda setting for the issue of climate change. The term collective influence, as used here, represents the influence of the body of scientists doing work surrounding climate change. While individual scientists have an impact on the policy process, we argue that perceptions of community influence hold implications for the behaviour of individual scientists. Major policy process theories build on Wildavsky's (1979) work by placing scientists in important roles with respect to agenda setting in particular (Baumgartner and Jones 1993; Kingdon 1995). Scientists play a crucial part in maintaining agenda status for climate change policy in the United States (US); however, we know very little about how scientists perceive their collective influence. In addition, scientists' perception of their collective relationship with policymakers is also unclear. These relationships are frequently strained, given the often divergent goals of politics and science (Sarewitz 2000, 2004; Rosenbaum 2013). Scholars have identified good relationships as one criterion for policy success (Van Buuren and Edelenbos 2004; Runhaar and Nieuwaal 2010). As such, understanding perceptions of scientists regarding these relationships is important.

For the purposes of this study, we consider the relationships between climate scientists and policymakers in the US from the perspective of the 
scientists. Despite a clear rationale for the use of scientific information and the need for working relationships between scientists and policymakers, there are still a number of open questions about these relationships and the factors that lead to their development. How much do US climate scientists feel they contribute to agenda setting, and how might they characterise their collective relationship with policymakers? What factors shape the beliefs that climate scientists have about their collective relationships and influence on policymakers? These questions are of increasing importance given the complexity of modern society. The passage of public policy is, in part, dependent on these relationships (Hunt and Shackley 1999; Cortner 2000; Van Buuren and Edelenbos 2004). Hunt and Shackley (1999) argue that the integration between scientists and policymakers is primarily driven by how close the relationships are between the two. If scientists do not believe their research and expertise is appreciated or wanted by policymakers, they may not be motivated to engage in the policy process, which may limit the ability of policy to adequately address complex issues. As such, a broad set of literature considers the context under which science is most often utilised by policymakers (e.g. Weible 2008; Montpetit 2011). This literature, however, does not directly consider the shaping of scientists' attitudes about their relationship with policymakers, which leaves out a significant part of this picture. $^{1}$

There have been several studies that aim to dissect and disentangle the relationships between scientists and policymakers. We contribute to this work by directly considering the views of scientists as to their collective role in agenda setting and their perceptions of their working relationships with policymakers. To address our research questions, we utilise a survey of climate scientists in the US. Ultimately, we are interested in explaining the factors that affect relationships and influence perceptions among scientists. Knowing the factors relevant to these perceptions can inform the ways in which these relationships can be improved. We find that trust and contact with policymakers, in addition to their attitudes about climate change, play an important role in shaping the relationships and influencing the perceptions of scientists.

\section{The case for analysing climate scientists}

Climate change is considered by many to be one of the most (if not the most) severe environmental problems facing the US and other nations.

\footnotetext{
${ }^{1}$ There are many definitions of attitudes within the literature. However, the social psychology literature generally agrees that attitudes provide a mechanism for evaluating an idea, typically in positive or negative terms, and that attitudes are malleable while simultaneously being fairly consistent (see Banaji and Heiphetz 2010).
} 
In addition, climate change is similar to many other complex scientific issues in terms of salience and controversy. One could compare climate scientists to those working on stem cell research, genetically modified foods or environmental problems that have exhibited uncertainty and controversy in the past (e.g. acid rain). Despite these similarities, this issue is somewhat unique within the realm of environmental policy.

Policy decisions with regard to climate change are made at multiple levels, and coordination within the international community is needed to adequately address the problem (Ostrom 2010; Selin and VanDeveer 2013). This distinguishes climate change from more domestic environmental issues that do not cross national boundaries. In addition, while there is a great deal of scientific consensus surrounding the problem's existence and general causes (IPCC 2013), uncertainty about specific effects and levels of risk are relatively high, particularly among the public in the US (Leiserowitz 2006). Global implications are more certain than are smaller scale impacts (Gough and Shackley 2001). Despite these differences, environmental issues all contain a level of technical complexity. Similarly, uncertainty is not something only felt for the issue of climate change. There are other global environmental problems, such as ozone depletion and sustainability, that have shared similar levels of uncertainty in times past. In the case of ozone depletion, the level of uncertainty about its direct causes was fairly high, even as policymakers negotiated the Montreal Protocol. In this case, epistemic communities were able to provide knowledge and encourage a policy strategy that prevailed (Haas 1992b). We anticipate that findings regarding climate scientists are generalisable to other scientific issues that generate controversy and that cross international borders. ${ }^{2}$

\section{The role of scientists in the policy process}

Studies that examine the science-policy interface do so through a variety of lenses. A series of work considers what the "best" role is for scientists when helping political actors decide on policy options and goals (e.g. Wildavsky 1979). Steel et al. (2004) trace evolving conceptions of science, finding that the more traditional role for scientists is as an objective provider of expertise that policymakers use to make decisions, while the more recently developed roles range from active participants in the decision or

${ }^{2}$ While there are institutional, societal and economic development differences between most of the countries in the world, the characteristics examined in this project should serve as predictors of similar attitudes among climate scientists in other countries. With the exception of trust in states, none of the specific variables used in the analyses are unique to the US, and therefore should provide results that are generalisable beyond the US. 
management process to a supplier of information. In this case, science is explained through stages of decision making, and scientists may even advocate for a position if their expertise demands it. ${ }^{3}$ Of course, groups and individuals vary in terms of what they believe scientists should do.

Pielke's (2007) typology of scientific roles illustrates this variance. For Pielke, scientists fall into one of four categories: the pure scientist, the science arbiter, the issue advocate or the honest broker. These roles range from very little involvement with policymakers to an active and/or clarifying role. ${ }^{4}$ Some scientists feel an obligation or duty to engage and discuss findings with the public (Pearson et al. 1997). In addition, scientists engage more frequently when they feel their colleagues are also doing so (Poliakoff and Webb 2007). Surveys conducted by Anderson and Betsill (2010) reveal that scientists find engaging in the policy sphere to be very appropriate, though many draw the line at outright associations with advocacy groups and report that engagement can become too involved. However, climate scientists often engage with environmental advocacy groups (BromleyTrujillo et al. 2014). Clearly, not all scientists are in complete agreement on what their role in the policy sphere should be. When asked, scientists give disparate answers about their role in the policy process (Steel et al. 2004). This highlights the potential for scientists working in different fields to view their relationships and influence with policymakers differently.

Heinrichs (2005) finds that scientists in both the US and Germany are highly involved in consulting with policymakers. He argues that the policy function of scientists should focus on short-term, well-defined policy problems rather than more abstract and long-term goals. For an issue like climate change, this role for scientists is rather difficult. Climate change is a long-term, abstract issue. This portion of the literature often advocates for various roles for scientists, yet it is still unclear what role scientists actually believe they play and how much influence they believe they exert.

Another line of research primarily considers the underutilisation of science and, in particular, how scientists facilitate this problem (Turnhout et al. 2008; Runhaar and Nieuwaal 2010). Runhaar and Nieuwaal (2010) consider how policy activity has developed concerning cockle fisheries. They note two periods of activity, with the first being characterised as one dominated by scientists and the second incorporating both scientists and

\footnotetext{
3 This increased advocacy has led to the perception that scientists may be overtly political (Martin and Richards 1995).

${ }^{4}$ A pure scientist focuses on research and does not have direct contact with decision makers, while a science arbiter would answer specific questions asked by policymakers. Issue advocates narrow the debate to a policy choice they advocate. An honest broker may expand the debate and offer clarification over policy options.
} 
stakeholders. The latter period is argued to be a policy success due, in large part, to an alignment of research and decision-making processes.

Turnhout et al. (2008) examine the role of scientists through several phases of the policy process as it pertains to the Wadden Sea. The authors argue that the role of scientists varies depending on the stage of the policy process and the structure of policy contents. Scientists may choose to advocate, identify the problem and help solve the problem, or accommodate policymakers' choices. Turnhout et al. (2008) distinguish policy problems with regard to their level of structure. Structured policy problems are technical and scientists step in to problem solve, given their expertise. A badly structured policy problem typically includes a lack of understanding as to the goals or process of achieving goals, while scientific uncertainty is high. For moderately structured problems, there exists disagreement over what should be done and competition between advocacy coalitions ensues. In this case, scientists may act as policy brokers. Climate change may best represent a moderately structured problem where scientists continue to highlight the problem to further policy deliberation.

Scholars also consider how networks of experts influence decision making. This line of inquiry incorporates an analysis of epistemic communities, in addition to advocacy coalitions. Many of the scientists we surveyed are likely to be considered players within these networks. Epistemic communities consist of knowledge-based individuals who share a recognised expertise and a common policy concern. Epistemic communities are able to influence the policy process through control of the production of knowledge. Ultimately, this allows experts to guide the learning process for decision makers (Haas 1992a, 1992b; Dunlop 2009). The epistemic community framework suggests that problem uncertainty and considerations over the effect of policy options lead decision makers to seek out information from epistemic communities (Meijerink 2005). While this theory is primarily discussed in accordance with international actors, others argue that these communities exist at smaller scales (Rose 1991).

Similarly, the ACF denotes the importance of networks for policy change, though advocacy coalitions share a set of values, while epistemic communities are primarily formed through shared knowledge. The ACF specifically identifies scientists as individuals who play a key role as policy brokers and as providers of information that may adjust belief systems and that can be used by competing advocacy coalitions (Weible et al. 2011). In the case of climate change, it appears that both of these types of networks are in existence, imparting information to policymakers and advocating on behalf of specific strategies to achieve a particular set of goals.

Engagement between scientists and policymakers depends, in part, on the level and branch of government being considered. Schooler (1971) finds 
that the strongest connection is between scientists and the executive branch, while other connections between scientists and Congress, state and local governments appear to be temporary, or ad hoc. However, Anderson and Betsill (2010) find that very limited engagement occurs between climate scientists and policymakers. Similarly, Stoutenborough et al. (2014b) find that climate scientists are approximately equally likely to be contacted by national and state/local officials. However, they find that most scientists are rarely contacted at all and are unlikely to initiate contact with government officials of any kind. Part of this may be a recognition that scientific knowledge is often brought into the policy debate only if it supports a preexisting policy perspective (e.g. Boswell 2009). This pseudo-influence may cause scientists to distrust officials when they do request information. ${ }^{5}$

Historical accounts also provide some clarification about the relationships between scientists and policymakers. Corfee-Morlot et al. (2007) trace the evolution of climate change and its movement from a scientific issue to a prominent public policy issue with some discussion of the changing relationships between scientists and policymakers (see also Keller 2009). The authors find that the prominence of this issue actually proves to make discussions between scientists and policymakers more difficult. This may cause policymakers to prefer discussing these issues with scientists who support long-term strategies that can be developed over a period of time rather than quick fixes. Importantly, long-term policy strategies are likely to fall outside of media attention long enough to allow for a meaningful discussion, whereas policies that need to be adopted rapidly are more likely to generate attention. These two strategies are apparent in climate change, where scientists advocating for mitigation strategies insist action is needed immediately. Meanwhile, those supporting an adaptation strategy believe that we can wait for the externalities associated with climate change to show themselves before acting.

\section{Scientists and agenda setting}

While much of this literature suggests a role for scientists in the formulation and implementation of public policy, it is important to note the large role scientists play in agenda setting. Agenda setting theories suggest that scientists work with a number of other actors in bringing new issues to governmental and public agendas (Baumgartner and Jones 1993; Kingdon 1995). Despite this,

\footnotetext{
${ }^{5}$ Psychologists suggest that trust is a component of two constructs - social values similarity and competence (e.g. Cvetkovich and Nakayachi 2007). When scientists get pulled into political games, it appears as though this distrust is manifested in the belief that politicians are not competent (see Stoutenborough et al. 2014b).
} 
issues do not necessarily come to the agenda at a time when the problem is actually the most severe or when scientific information is plentiful. Policymakers may underreact to one problem while overreacting to others (Jones and Baumgartner 2005a, 2005b). Governmental agendas are ultimately limited in capacity, with room for only so many issues (Cobb and Elder 1983; Hilgartner and Bosk 1988). Issues may fall off of the agenda for some time and reappear with renewed focus and potentially excessive attention later (Jones and Baumgartner 2005b). Scientists can help put back on the agenda issues that have fallen off. Scientists' perceptions about the influence of their community can alter the behaviour of individual scientists. If scientists believe they have some influence, they may also be more likely to engage with the public and the policy community (Poliakoff and Webb 2007). In turn, this engagement is likely to result in additional influence on the policy agenda.

Climate change in particular has seen movement on and off public and governmental agendas over the past two decades, with scientists working to restore its position on the agenda. For example, the "Keeling curve" demonstrated drastic increases in carbon dioxide and sparked a great deal of early interest and concern over climate change (Kolbert 2006). Since then, scientists continue to stress the importance of climate change through academic research, reports, and contact with policymakers. Pralle (2009) notes the importance of keeping climate change on a variety of agendas (governmental, non-governmental and public) given the scale of the issue and the need for continued action. If climate change continues to fall off governmental agendas and to be displaced by other issues, it will unlikely be fully addressed. This makes understanding how scientists perceive their collective influence on agenda setting even more important. If scientists perceive their impact to be minimal, they may choose to play a more diminished role in the policy process.

\section{Surveying scientists}

While studies provide a fairly rich discussion regarding the role of scientists in the policy process, including an emphasis on agenda setting, there is a fairly small body of work asking scientists about their perceptions of the collective role of their community. Scientists are motivated by the actions of their colleagues and by their perceptions of the policy community (Shackley et al. 1999; Poliakoff and Webb 2007; Holmes and Clark 2008; Keller 2009; Ascher et al. 2010). Despite this, surveys of scientists concerning their relationship with, and influence on, policymakers are infrequent. Few have examined how scientists view their possible influence, and studies that have considered influence in this way are dated (e.g. Gianos 1974). Gianos finds 
that scientists indicate influence in narrow areas, while influencing policy at the margins. In his survey, scientists who work inside government feel they have slightly more influence. Similarly, scientists who feel "at home in government" may feel their relationship and influence is generally stronger. In more recent surveys of scientists, Alm (2002-2003) finds that scientists who study acid rain generally believe that policymakers are "ignorant with respect to how the scientific process works". Much is left unanswered from these studies to explain why scientists perceive a certain level of influence and quality of relationships. ${ }^{6}$

While the literature on scientists' perceptions is limited, there are theoretical expectations we can glean from these studies and the larger body of work on the role of science in the policy process. The studies discussed suggest that mistrust and/or concern over how policymakers will utilise scientific information leads to breakdowns in relationships and can also effect perceptions of influence. The literature suggests that contact is not consistent between scientists and policymakers, which likely contributes to the strength of the relationships between the two. The policy process literature has left these theoretical expectations largely untested, and thus we aim to fill this gap.

\section{Analytical approach}

To understand the perceptions of climate scientists on their collective relationship with and influence on government, we utilised a survey of climate scientists in the United States. The survey employed a journal-based sampling frame consisting of 13 internationally renowned scientific journals that are the most cited within the field. ${ }^{7}$ We examined all of the articles from these journals from 1995 through 2004 that were related to global warming and climate change. This identified a total of 929 US authors. All 929 were asked to participate in the survey between March and

\footnotetext{
${ }^{6}$ Heinrich's (2005) examination of German and American scientists may be an exception, but there is still a great deal about this relationship that remains a mystery.

7 The 13 journals sampled were Global Environmental Change, Journal of Climate, Journal of Atmospheric Sciences, Journal of Geophysical Research, Climatic Change, Journal of Applied Meteorology, Monthly Weather Review, Journal of Atmospheric and Oceanic Technology, Weather and Forecasting, Journal of Hydrometeorology, Earth Interactions, Bulletin of the American Meteorological Society and Meteorological Monographs. They were selected based upon discussions with climate scientists, impact factors, meteorology association publications, and other relevant data. We believe this makes our sample representative of, at least, climate scientists who are actively engaging in and publishing research. This should represent the leading edge of climate change research, which should represent the climate scientists most likely to engage in the policy process.
} 
September, 2005. We were able to complete 514 scientist interviews for a response rate of $55 \% .^{8}$

Because little is known about how US climate scientists perceive their association with government, we focused on two questions that capture two important characteristics of this rapport. The first was an examination of their perceptions about the relationship between climate scientists, as a whole, and government officials. This dependent variable was based on the question, "How would you describe the working relationship between climate scientists and policymakers?" The answer choices were on an 11-point scale, where 0 was "no relationship" and 10 was a "very strong relationship". The second examination explored the amount of influence that climate scientists believe they have, as a whole, on the agenda setting stage of the policy process. This dependent variable was constructed from the question, "How much of a role do you think scientists have played in transforming the climate issue from being a scientific issue to a public policy issue?" This question also employed an 11-point scale, where 0 represented "no role" and 10 a "very important role". The non-continuous, ordered nature of the dependent variables indicates that an ordered logit was the most appropriate analytical approach.

Not surprisingly, as illustrated in Figure 1, these 11-point scales resulted in data that were skewed toward the lower end of the scale for the relationship question and toward the upper end of the scale for the influence question. Because of the ordered nature of this data and the limited number of responses on the tails, there are concerns about the ability of the model to accurately estimate the relationships between the variables due to too many empty bins in the data (see McCullagh and Nelder 1989). For instance, only one respondent believed the relationship between climate scientists and policymakers warranted a score of 9 on the $0-10$ scale, and none of the scientists believed their collective influence merited a score of 0 . To correct for this, we collapsed the 11-point scales to a 6-point scale for each variable. In both cases, the tails were collapsed to allow sufficient observations while retaining the original nature of the data. ${ }^{9}$

An ordered logit is typically thought of as an appropriate statistical approach to account for an ordered, non-continuous dependent variable like those in the present study (McKelvey and Zavoina 1975). However, it is important to acknowledge the potential for a violation of the parallel regression assumption, which maintains that the influence of a variable is constant across the entire

${ }^{8}$ We utilised several modalities to contact the climate scientists, including mail surveys, Internet-based surveys and personal telephone interviews.

${ }^{9}$ The relationship variable combined observations of 0 and 1 together, as well as 6 through 10 . The influence variable combined 0 through 4 , and 9 and 10 . 


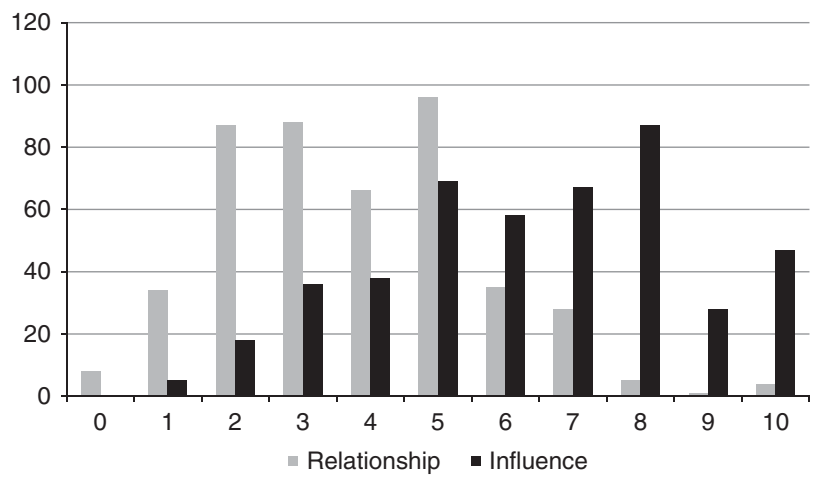

Figure 1 Climate scientist perceptions of their relationship with government officials and influence on the agenda.

Source: Compiled by authors.

range of the dependent variable (Long 1997). Violations of this assumption can result in a misinterpretation of the relationship between the dependent variable and the violating independent variable (e.g. Robinson et al. 2013; Stoutenborough et al. 2013). We tested the assumption using a Brant Test (Williams 2006), and consequently, we decided it was best to use a generalised ordered logit (GOLOGIT) model approach.

The literature is not particularly clear concerning what might affect perceptions of scientists' collective relationship with policymakers or the collective influence of scientists on agenda setting. Therefore, based on the above discussion, we employed a broad approach that captures characteristics consistent with the literature discussed above that may influence the dependent variables. Specifically, we broke these variables into seven categories - attitudes, trust, contact, policy relevance, employer, field of study and demographics.

We tested for the influence of two general attitudes about climate change. The first measured the scientists' belief that the US will be able to adopt policies that effectively mitigate climate change. The second assessed their belief that the US will be able to adapt to climate change if we were unable to mitigate. These were measured separately because it was possible that there was a bit of a selection bias on the part of government officials that may have affected the perceptions of climate scientists. For instance, policymakers may have a better relationship with those who believe that the US will be able to adapt, because that would allow the policymaker to continue to delay acting on the issue. The punctuated equilibrium theory discusses how policymaking often resembles incrementalism until there is a focusing event that causes punctuation (e.g. Baumgartner and Jones 1993; 
True et al. 2007). Essentially, punctuated equilibrium theory tells us that policymaking is reactive in nature, and rarely proactive, even when potential problems have been known long before the focusing event (see e.g. van Heerden and Bryan 2006). Consequently, policymakers should prefer to pursue adaptation strategies, because it allows them to postpone action until a focusing event forces them to act. On the other hand, those who believe that the US could effectively mitigate climate change may believe they have more of a collective influence on the agenda since any legislative attempt to mitigate must occur soon, and nearly all of the current political debates concerning climate change involve mitigation strategies. ${ }^{10}$

Perceptions of trust may also affect these relationships and influence. Typically, it is difficult to hide our views when working with people whom we do not trust, and we tend to have a better working relationship with those whom we do trust (Ullmann-Margalit 2004). Therefore, we expect that if a scientist believes officials are not trustworthy, it would likely affect how that person views scientists' collective relationship with officials and their ability to influence the agenda (Holmes and Clark 2008). We included three specific measures of trust to control for this impact - federal officials, local officials and state officials. We turned to the psychological research on trust to identify how to best capture how trust can influence specific attitudes. This research has identified two primary criteria that are used by individuals to evaluate trust - competence and shared values (e.g. Nakayachi and Cvetkovich 2010). Robinson et al. (2013) argue that competence is the best indicator of trust when dealing with an institution where competence is essential to their duties. If the government is incompetent, it will be unable to adequately solve the problems facing its constituents. In terms of climate change, an incompetent government is one that refuses to act to limit/prevent the negative externalities associated with climate change. Given the inability of various levels of government to enact climate change legislation, competence appears to be the most appropriate of the two components to measure. It is possible that variations in trust for the different levels of government could be influencing these dependent variables.

Everyone likes to believe that others appreciate their work. For climate scientists and their rapport with policymakers, this should manifest itself in the efforts of policymakers to contact climate scientists for information. Scientists tend to gain a level of comfort when working with or in government as the level of engagement increases (Giano 1974; Keller 2009; Ascher et al. 2010), which should improve perceptions of influence and relationship. Therefore, we controlled for those who had been contacted by federal

\footnotetext{
${ }^{10}$ We are specifically speaking to the ability of climate scientists in the US to influence the political agenda and not necessarily the successful adoption of a policy.
} 
officials and/or state/local officials to discuss climate change in the previous five years. We expected that those who have been contacted more often are going to view this contact more favourably. The more often a scientist is contacted, the greater the likelihood that this person evaluates the collective relationship and influence of climate scientists at the higher end of the scale. ${ }^{11}$

It is also possible that policy relevance could influence perceptions of climate scientists. If scientists believe their personal research is relevant to policymakers, then it is more likely that they will overestimate the influence of climate scientists, as a group, on the policy agenda because their personal experience is generally positive. Similarly, we expected to find that those who believe their personal research is policy relevant would believe climate scientists, as a group, have a better relationship with policymakers. We controlled for four different policy domains that conduct climate-related research - public health, economic development, agriculture and land use.

As noted, certain employers are likely to have better access to government officials than others. Moreover, different types of employers are likely to be associated with different levels of government access. For instance, a scientist who works for a federal agency should have greater access to policymakers than a nonprofit or university scientist (Giano 1974). The overwhelming majority of the scientists who participated in the survey worked in a federal agency, government lab or in a university setting. Therefore, we controlled for these three environments.

Similar to the previous two characteristics, perceptions of the influence and relationship with policymakers could be influenced by the specific field of study. Scientists in certain fields may believe they have greater access than others. Additionally, scientists in different fields view their role in the policy process differently (Steel et al. 2004). We controlled for eight fields of study - physics, atmospheric physics, ecology, geography/forestry, oceanography, social science, math and engineering.

Studies of attitudes, beliefs and opinion also consistently find that demographic characteristics are important predictors. While we did not have any specific expectations with regard to the direction of these relationships in this particular analysis, we do know that there are demographic differences between climate scientists that influence other behaviours (Bromley-Trujillo et al. 2014). Accordingly, we controlled for the influence of ideology, income, gender, age and race to ensure that there were no underlying differences that would predict these specific beliefs. ${ }^{12}$

${ }^{11}$ We presume that scientists are being contacted because of their expertise and that this should result in improved perceptions of relationship and influence.

${ }^{12}$ We did not ask the climate scientists to reveal their party identification, and education was not determined since they all had post-secondary education. 


\section{Results}

Before we begin analysing the results of the statistical models, we would like to take a moment to explain the presentation of these estimates. The GOLOGIT allows for a more efficient analysis when violations are present. In a traditional ordered logit, a coefficient would have a static influence across the range of the dependent variable. However, the GOLOGIT permits the variables in violation of the parallel regression assumption to vary across the dependent variable, which allows for a more efficient estimation of their impact on the dependent variable and for the possibility that a variable may gain or lose statistical significance (e.g. Bies et al. 2013; Robinson et al. 2013; Stoutenborough et al. 2013, 2014a).

In the tables presented below, variables that were in violation of the parallel regression assumption have their estimates broken down based on each level of the dependent variable. Because there are six possible values for the dependent variable, there are five levels examined in the models. For example, Level 1 corresponds to the contrast between 0 against all of the other ordered categories; Level 3 examines the contrast between the 0, 1 and 2 categories against the 3, 4 and 5 categories; Level 5 represents the analysis of 5 against all of the previous categories. The operational coding for these ordered dependent variables create five simultaneously estimated logit analyses (Williams 2006). In the above examples, Level 1 is operationally coded as the 0 ordered category being coded as 0 and the 1 through 5 categories coded as 1 ; Level 3 is coded with the 0,1 and 2 categories treated as the 0 and the 3, 4 and 5 categories as 1 ; Level 5 treats the 0 through 4 ordered categories as the 0 and the 5 category as the 1 . Additionally, $\gamma$ estimates are reported. $\gamma$ estimates are tests to determine if the coefficient estimate at any level above Level 1 is significantly different from the estimate at Level 1 . This identifies the specific levels of the dependent variable where the independent variable violates the parallel regression assumption.

\section{Relationship}

The GOLOGIT results for the analysis of perceptions of the relationship between climate scientists and policymakers are presented in Table 1. The results indicate that the two attitudinal categories - attitudes and trust have the strongest impact on perceptions of this relationship. As anticipated, we find that those scientists who think the US will be able to adapt to climate change are more likely to believe that climate scientists have a good relationship with policymakers. Additionally, the GOLOGIT reveals that those who trust federal and local officials are more likely to believe climate 
Table 1. Climate scientists' relationship with government officials

\begin{tabular}{|c|c|c|}
\hline & Coefficient & Probability \\
\hline \multicolumn{3}{|l|}{ Attitudes } \\
\hline US mitigation & $-0.046(0.088)$ & 0.597 \\
\hline US adaptation & $0.444(0.104)$ & 0.000 \\
\hline \multicolumn{3}{|l|}{ Trust } \\
\hline Federal officials & $1.014(0.147)$ & 0.000 \\
\hline Local officials & $0.356(0.176)$ & 0.042 \\
\hline State officials & $-0.333(0.188)$ & 0.076 \\
\hline \multicolumn{3}{|l|}{ Contact } \\
\hline Federal officials & $-0.263(0.276)$ & 0.341 \\
\hline State or local officials & $0.580(0.258)$ & 0.025 \\
\hline \multicolumn{3}{|l|}{ Policy area relevance } \\
\hline Public health & $-0.032(0.097)$ & 0.736 \\
\hline Economic development & $-0.060(0.112)$ & 0.590 \\
\hline Agriculture & $0.190(0.114)$ & 0.097 \\
\hline Land use & $0.056(0.110)$ & 0.605 \\
\hline \multicolumn{3}{|l|}{ Employer } \\
\hline Federal agency & $0.101(0.375)$ & 0.787 \\
\hline Government lab & $0.185(0.136)$ & 0.175 \\
\hline University & $0.073(0.065)$ & 0.263 \\
\hline \multicolumn{3}{|l|}{ Field of study } \\
\hline Physics & $0.851(0.412)$ & 0.039 \\
\hline Atmospheric physics & $0.630(0.299)$ & 0.035 \\
\hline Ecology & $1.343(0.393)$ & 0.001 \\
\hline Geography/forestry & $0.590(0.552)$ & 0.285 \\
\hline Oceanography & $0.308(0.427)$ & 0.470 \\
\hline Social science & $-0.001(0.452)$ & 0.998 \\
\hline Math & $0.171(0.500)$ & 0.731 \\
\hline \multicolumn{3}{|l|}{ Engineering } \\
\hline Level 1 & $-0.480(1.231)$ & 0.696 \\
\hline Level 2 & $-0.795(0.985)$ & 0.420 \\
\hline Level 3 & $-14.123(471.486)$ & 0.976 \\
\hline Level 4 & $15.013(746.576)$ & 0.984 \\
\hline Level 5* & $3.072(1.189)$ & 0.010 \\
\hline \multicolumn{3}{|l|}{ Demographics } \\
\hline Liberal & $-0.317(0.227)$ & 0.163 \\
\hline Income & $0.077(0.082)$ & 0.348 \\
\hline Female & $0.504(0.294)$ & 0.087 \\
\hline Age & $-0.0002(0.011)$ & 0.986 \\
\hline White & $0.401(0.322)$ & 0.213 \\
\hline Cut Point 1 & $-1.179(0.876)$ & \\
\hline Cut Point 2 & $-2.811(0.878)$ & \\
\hline Cut Point 3 & $-3.896(0.888)$ & \\
\hline Cut Point 4 & $-4.636(0.896)$ & \\
\hline Cut Point 5 & $-6.058(0.919)$ & \\
\hline Number of cases & 357 & \\
\hline
\end{tabular}


Table 1. Continued

\begin{tabular}{lcc}
\hline & Coefficient & Probability \\
\hline Wald $\chi^{2}$ & 116.79 & 0.0000 \\
McFadden's $R^{2}$ & 0.1173 & \\
Log likelihood & -554.739 & \\
\hline \hline
\end{tabular}

Note: Cell entries are generalised ordered logit regression coefficients. Standard errors are in parentheses. Two-tailed test. Variables that violated the parallel regression assumption vary across the range of the dependent variable. Level 1 corresponds to the contrast between 0 against all of the other categories; Level 3 examines the contrast between the 0,1 and 2 against 3, 4 and 5, while Level 5 represents the analysis of 5 against the other categories.

$\gamma$-test if coefficient estimates at Levels 2, 3, 4 or 5 are significantly different than at Level 1: ${ }^{*} \mathrm{p}<0.05 ;{ }^{* *} \mathrm{p}<0.01$.

scientists have a good relationship, while those who trust state officials feel they collectively have a poor relationship.

The more often a climate scientist is contacted by state or local officials, the better the perceived collective relationship. Moreover, the model indicates that those with policy relevance related to agriculture are marginally more likely to believe climate scientists have a good relationship with policymakers. Although we fail to find a significant predictor between type of employer and relationship, the model does indicate that those who study physics, atmospheric physics and ecology are more likely to believe climate scientists have a good relationship with policymakers. Engineers, the lone variable in violation of the parallel regression assumption, are also more likely to believe climate scientists have a good relationship, but only at Level 5, which compared those with the strongest belief in a good relationship against all of the lower levels of belief. This suggests that engineers are much more likely to believe climate scientists have a very strong relationship. Finally, the analysis finds that female scientists are marginally more likely to believe that climate scientists have a good relationship with policymakers.

\section{Influence}

The analysis of perceptions of the influence of climate scientists on the agenda is presented in Table 2. This analysis included seven variables that violated the parallel regression assumption, which resulted in a rather large and complex presentation of these results, but this allows for a nuanced analysis of the predictive power of the variables. As expected, the GOLOGIT finds that those who support the mitigation strategy are more 
Table 2. Climate scientists' influence on agenda

\begin{tabular}{|c|c|c|}
\hline & Coefficient & Probability \\
\hline \multicolumn{3}{|l|}{ Attitudes } \\
\hline \multicolumn{3}{|l|}{ US mitigation } \\
\hline Level 1 & $0.777(0.141)$ & 0.000 \\
\hline Level $2 * *$ & $0.490(0.119)$ & 0.000 \\
\hline Level $3 * * *$ & $0.143(0.109)$ & 0.192 \\
\hline Level $4 * * *$ & $0.150(0.110)$ & 0.173 \\
\hline Level $5^{\dagger}$ & $0.438(0.147)$ & 0.003 \\
\hline US adaptation & $0.144(0.099)$ & 0.147 \\
\hline \multicolumn{3}{|l|}{ Trust } \\
\hline Federal officials & $0.105(0.136)$ & 0.438 \\
\hline \multicolumn{3}{|l|}{ Local officials } \\
\hline Level 1 & $0.095(0.221)$ & 0.667 \\
\hline Level 2 & $0.234(0.195)$ & 0.229 \\
\hline Level $3^{\dagger}$ & $-0.238(0.187)$ & 0.203 \\
\hline Level 4* & $-0.372(0.196)$ & 0.058 \\
\hline Level $5^{\dagger}$ & $-0.317(0.217)$ & 0.144 \\
\hline State officials & $0.581(0.195)$ & 0.003 \\
\hline \multicolumn{3}{|l|}{ Contact } \\
\hline \multicolumn{3}{|l|}{ Federal officials } \\
\hline Level 1 & $0.932(0.460)$ & 0.043 \\
\hline Level $2 * *$ & $-0.155(0.335)$ & 0.642 \\
\hline Level 3 & $0.300(0.318)$ & 0.345 \\
\hline Level 4 & $0.584(0.317)$ & 0.066 \\
\hline Level 5 & $0.556(0.369)$ & 0.133 \\
\hline State or local officials & $0.611(0.266)$ & 0.022 \\
\hline \multicolumn{3}{|l|}{ Employer } \\
\hline Federal agency & $0.330(0.395)$ & 0.403 \\
\hline Government lab & $0.160(0.146)$ & 0.275 \\
\hline \multicolumn{3}{|l|}{ University } \\
\hline Level 1 & $-0.097(0.082)$ & 0.233 \\
\hline Level $2 *$ & $-0.001(0.074)$ & 0.984 \\
\hline Level $3 * *$ & $0.100(0.074)$ & 0.178 \\
\hline Level $4 * *$ & $0.075(0.076)$ & 0.323 \\
\hline Level $5 *$ & $0.115(0.086)$ & 0.183 \\
\hline \multicolumn{3}{|l|}{ Field of study } \\
\hline Physics & $0.124(0.429)$ & 0.772 \\
\hline Atmospheric physics & $0.327(0.316)$ & 0.301 \\
\hline Ecology & $0.645(0.416)$ & 0.121 \\
\hline Geography/forestry & $1.082(0.535)$ & 0.043 \\
\hline Oceanography & $0.211(0.439)$ & 0.630 \\
\hline Social science & $0.065(0.470)$ & 0.890 \\
\hline Math & $0.064(0.525)$ & 0.903 \\
\hline \multicolumn{3}{|l|}{ Engineering } \\
\hline Level 1 & $-1.639(1.053)$ & 0.120 \\
\hline Level 2 & $-1.118(1.308)$ & 0.393 \\
\hline
\end{tabular}


Table 2. Continued

\begin{tabular}{lcc}
\hline & Coefficient & Probability \\
\hline Level 3 & $-14.342(1114.054)$ & 0.990 \\
Level 4 & $16.659(1092.635)$ & 0.988 \\
Level 5* & $2.024(1.052)$ & 0.054 \\
Policy area relevance & & \\
Public health & $0.228(0.097)$ & 0.019 \\
Economic development & $0.112(0.112)$ & 0.320 \\
Agriculture & $-0.210(0.113)$ & 0.064 \\
Land use & $0.007(0.114)$ & 0.948 \\
Demographics & & \\
Liberal & $-0.042(0.224)$ & 0.849 \\
Income & $0.097(0.080)$ & 0.226 \\
Female & & \\
Level 1 & $-1.164(0.397)$ & 0.003 \\
Level 2 & $-1.354(0.374)$ & 0.000 \\
Level 3** & $0.026(0.369)$ & 0.942 \\
Level 4*** & $0.293(0.373)$ & 0.431 \\
Level 5 & $-0.731(0.575)$ & 0.204 \\
Age & $0.003(0.010)$ & 0.736 \\
White & 117.98 & \\
Level 1 & 0.1344 & \\
Level 2*** & -549.374 & 0.011 \\
Level 3*** & $1.106(0.435)$ & 0.782 \\
Level 4*** & $0.104(0.377)$ & 0.803 \\
Level 5* & $0.089(0.360)$ & 0.435 \\
Cut Point 1 & $-0.285(0.365)$ & 0.900 \\
Cut Point 2 & $-0.056(0.451)$ & \\
Cut Point 3 & $-3.614(0.995)$ & \\
Cut Point 4 & $-3.236(0.931)$ & \\
Cut Point 5 & $-2.867(0.923)$ & \\
Number of cases & $-3.118(0.933)$ & \\
Wald $\chi^{2}$ & $-5.475(1.079)$ & \\
McFadden's $R^{2}$ & 358 & \\
Log likelihood & & \\
\hline \hline & & \\
\hline
\end{tabular}

Note: Cell entries are generalised ordered logit regression coefficients. Standard errors are in parentheses. Two-tailed test. Variables that violated the parallel regression assumption vary across the range of the dependent variable. Level 1 corresponds to the contrast between 0 against all of the other ordered categories; Level 3 examines the contrast between the 0,1 and 2 categories against 3, 4 and 5 categories, while Level 5 represents the analysis of 5 against all of the previous categories. $\gamma$-test if coefficient estimates at Levels $2,3,4$ or 5 are significantly different than at Level 1: ${ }^{\dagger} \mathrm{p}<0.100 ;{ }^{*} \mathrm{p}<0.05 ; * \mathrm{p}<0.01 ;{ }^{* * *} \mathrm{p}<0.001$. 
likely to believe climate scientists have an influence on the agenda in the lower levels of the dependent variable, but that this impact weakens toward the upper end of the dependent variable, before returning at the highest. This suggests that those who prefer a mitigation strategy do not believe that climate scientists have little influence (Level 1 and Level 2). However, those who prefer a mitigation strategy are no more or less likely to believe climate scientists have a moderate to fairly strong influence (Level 3 and Level 4). Those who support a mitigation strategy are more likely to believe that climate scientists have a very strong influence on the agenda (Level 5). Unlike perceptions of relationship, we find that those who prefer the adaptation strategy are no more likely to believe that scientists have any influence, which given the nature of adaptation strategies is not surprising.

The analysis also finds that those who trust state officials are generally more likely to believe climate scientists have influence. The GOLOGIT reveals that those who reported the highest level of trust in local officials are less likely to perceive influence at Level 4 of the dependent variable. This suggests that those who hold this perspective are generally less likely to believe that climate scientists have much of an influence. ${ }^{13}$ The analysis also finds that those who trust federal officials are no more or less likely to perceive influence.

We again find that scientists appear to like to be asked their opinion. Those who were contacted by state or local officials are more likely to perceive influence. However, we find a more nuanced association between those who were contacted by federal officials and the belief that climate scientists influence the agenda. Specifically, the GOLOGIT indicates that those with more contact are more likely to perceive influence at Level 1 and Level 4. This means that those with more federal contact are less likely to believe climate scientists have no influence (Level 1) and generally believe climate scientists have a fairly strong influence (Level 4), but we do not find this contact to be a predictor at the remaining three levels.

Scientists who conduct research related to public health believe that climate scientists have a strong influence on the agenda. Conversely, the GOLOGIT indicates that those who research agricultural issues are marginally less likely to believe climate scientists influence the agenda. Again, we find that the type of employer does not impact perceptions, despite certain types having greater access. However, we do find that those who study geography/forestry are more likely to believe climate scientists have influence. The GOLOGIT again reveals that engineers differentiate

${ }^{13}$ Remember, at Level 4, the dependent variable is coded 0 for categories 0 through 3 and coded 1 for 4 and 5. A significant negative value at Level 4 indicates that those who have higher levels of trust in local officials are less likely to believe climate scientists have a strong to very strong influence on the agenda. 
themselves at the highest level of the dependent variable (Level 5), where we find they are more likely to believe that climate scientists have a strong influence.

Finally, the GOLOGIT reveals that women are less likely to believe scientists have influence at the lowest two levels of the dependent variable, but are no different from men at the middle to highest levels. Additionally, white scientists are less likely to believe that scientists have no influence, but are no different from other races at all of the other levels.

\section{Discussion}

We began this project in an attempt to understand the perceptions of US climate scientists on the relationship and influence of their fellow climate scientists on the policy process. After reviewing the pertinent literature, we devised an analytical strategy that allowed us to empirically examine these perceptions. The results of these analyses allow us to draw several important observations about the rapport between climate scientists and policymakers.

The analyses find that those who believe the US will be able to adapt to climate change also believe that climate scientists have a better relationship with policymakers, and those who believe that the US can mitigate climate change believe scientists have more influence on the political agenda. As noted above, this is consistent with what we know about government action within punctuated equilibrium theory, which is to say that government tends to be reactive. This suggests policymakers should prefer pursuing adaptation strategies to mitigation, which is reflected in the analyses. As rational actors, which Mayhew (1974) refers to as single-minded seekers of reelection, this is most likely due to adaptation strategies allowing policymakers the opportunity to forgo unpleasant actions. This inevitably produces a less strained relationship with climate scientists who support adaption than with scientists who advocate mitigation, as mitigation requires more immediate action and is more likely to become salient. In the simplest terms, if scientists who prefer a mitigation strategy received resistance from policymakers, this would cause them to perceive a poor relationship. Conversely, if policymakers truly prefer an adaptation approach, then they should be more open and receptive when discussing adaptation strategies with scientists who also support this approach. In turn, this should cause those who espouse adapation to perceive a better relationship.

Not surprisingly, the need for immediate action reveals that those who prefer a mitigation strategy believe climate scientists have more influence on the agenda than those who advocate adaptation. In practical terms, there is little to actually adapt to at this time, as punctuated equilibrium suggests 
that this adaption would be in response to a focusing event, which explains why adaptation supporters perceive less influence for climate scientists. When an issue gets on the agenda, it tends to become increasingly salient, which can make it more contentious. Indeed, Corfee-Morlot et al. (2007) note that, as climate change became more salient, it became more difficult for scientists to discuss the issue with policymakers. Consistent with extant literature, we find that climate scientists who support mitigation believe that climate scientists generally have a strained relationship with policymakers.

It is unclear why trust in state officials behaves differently than trust in federal or local officials. This difference is even more perplexing given that those who trust state officials are less likely to believe that scientists have a good relationship with government officials, but still have more influence on the agenda. How can they have a poor working relationship but more influence? It is possible that there is a love/hate association between climate scientists and state officials that is associated with mitigation and adaptation strategies. States have been more proactive than the federal government in adopting policies to curtail climate change (Matisoff 2008). Certainly, the evidence suggests that scientists have followed Schattschneider's (1960) advice of venue shopping and have turned their attention to trying to influence state agendas. And, they appear to have been more successful in this venue, but these efforts may have caused their collective relationship with state officials to become strained. It is also difficult to know if climate scientists are primarily evaluating leader states or laggard states. We expect evaluations of state trust to differ depending upon the willingness of a state to adopt climate policies. Future surveys of climate scientists will need to be more specific when evaluating attitudes like trust.

Climate scientists appear to enjoy having their egos stroked by state and local officials more than by federal officials. It is possible that this is related to the increased likelihood of successfully influencing the agenda in the states versus at the federal level. The benefits of being contacted by federal officials may have a limited effect, because scientists are increasingly being used as pawns to further a predetermined position held by officials instead of influencing a specific policy (e.g. Boswell 2009). Consistent with observations from applications of the ACF (Sabatier and Zafonte 2001; Weible 2008) and others (Turnhout et al. 2008), it is also possible that climate scientists have been forced into the policy broker role at the federal level due to the bitter divide between Republicans and Democrats on climate change.

Issue domain specialisation has a minimal impact on the perceptions of relationship and influence. Gianos (1974) argues that scientists may only influence policy in narrow ways, which is reflected in the different domains. Our results concur as, with the exception of those researching agriculture 
and public health, one's issue domain has little impact on one's evaluations of climate scientists in general. It is not clear why public health is the only domain that is associated with a positive influence. The predictive effect of agriculture mirrors that of the difference between mitigation and adaptation and trust in state officials between the two models. While beyond the scope of this current investigation, it may be necessary to examine whether those in the policy domain of agriculture are more likely to believe in adaptation or mitigation or to trust in state officials.

Contrary to the dated research concerning scientists that feel more "at home" in government having more influence (Gianos 1974), we find little support for the premise that certain types of employers will have greater access to policymakers and therefore would elicit differing views toward climate scientists' influence and relationship. We fail to find evidence that policymakers show preference for any particular type of climate scientist. If policymakers preferred one group over the other, we would have expected to see this reflected in the overall evaluations of the scientists within these preferred groups, because they would be more likely to believe that all scientists are received in the same manner. In many ways, this is a very positive outcome. We hope that policymakers have an open mind when it comes to expertise, regardless of what type of organisation pays their salary. However, it is interesting that those who work for a federal agency are not more likely to believe climate scientists have a good relationship with policymakers or that scientists influence the agenda, despite appearing to have an inherent advantage in access. It is possible that the relationship between federal agency scientists and policymakers have soured since Gianos (1974).

Finally, this project provides valuable insight into the way climate scientists perceive their collective influence on and relationship with policymakers. This is important because these perceptions should effect the motivation of climate scientists to engage in the political process (see, e.g. Shackley et al. 1999; Poliakoff and Webb 2007; Holmes and Clark 2008; Keller 2009; Ascher et al. 2010). If climate scientists do not believe policymakers value the input of climate scientists, then there is little motivation to serve as policy brokers or to engage in networks that include policymakers. The problem with this is that climate change is arguably one of the more complex issues facing the world, which necessitates involvement from those who actually have expertise - climate scientists. If these experts believe that policymakers do not care to listen to climate scientists, then the government will be less likely to adopt adequate climate policy. We hope that this begins a dialogue to better understand why climate scientists may believe they collectively do not have a good relationship with or strong influence on policymakers. 


\section{Acknowledgement}

The authors would also like to thank the anonymous reviewers and the Executive Editor, Anthony Bertelli, for their helpful suggestions.

\section{Financial Support}

This material is based upon research conducted by the Institute for Science, Technology and Public Policy in the Bush School of Government and Public Service at Texas A\&M University and supported under Award No. NA03OAR4310164 by the National Oceanic and Atmospheric Administration (NOAA), US Department of Commerce. The statements, findings, conclusions, and recommendations are those of the authors and do not necessarily reflect the views of the National Oceanic and Atmospheric Administration or the Department of Commerce.

\section{References}

Alm L. (2002-2003) Science and Policy: The View from The World of Scientists. Journal of Environmental Systems 29(4): 299-310.

Anderson L. and Betsill M. (2010) Scientists' Perspectives on Navigating the Science-Policy Frontier. Presented at the Annual Meeting of the American Political Science Association, Washington, DC, http://ssrn.com/abstract=1643185. Accessed: 7 April 2015.

Arvai J., Bridge G., Dolsak N., Franzese R., Koontz T., Luginbuhl A., Robbins P., Richards K., Korfmacher K. S., Sohngen B., Tansey J. and Thompson A. (2006) Adaptive Management of the Global Climate Problem: Bridging The Gap between Climate Research and Climate Policy. Climatic Change 78(1): 217-225.

Ascher W., Steelman T. A. and Healy R. G. (2010) Knowledge and Environmental Policy: Re-Imagining The Boundaries of Science and Politics. Cambridge, MA: The MIT Press.

Banaji M. R. and Heiphetz L. (2010) Attitudes. In Fiske S. T., Gilbert D. T. and Lindzey G. (eds.), Handbook of Social Psychology, vol. 1. New York: John Wiley \& Sons, 353-393.

Baumgartner F. R. and Jones B. D. (1993) Agendas and Instability in American Politics. Chicago: University of Chicago Press.

Bies A. L., Lee D. G., Lindsey C., Stoutenborough J. W. and Vedlitz A. (2013) Citizens, Nonprofits and Climate Change Policy. Nonprofit Policy Forum 4(1): 5-28.

Boswell C. (2009) The Political Uses of Expert Knowledge: Immigration Policy and Social Research. Cambridge: Cambridge University Press.

Bromley-Trujillo R., Stoutenborough J. W., Kirkpatrick K. J. and Vedlitz A. (2014) Climate Scientists and Environmental Interest Groups: The Intersection of Expertise and Advocacy. Politics, Groups, and Identities 2(1): 120-134.

Cobb R. W. and Elder C. D. (1983) Participation in American Politics: The Dynamics of AgendaBuilding. Baltimore, PA: John Hopkins University Press.

Corfee-Morlot J., Maslin M. and Burgess J. (2007) Global Warming in The Public Sphere. Mathematical, Physical and Engineering Sciences 365(1860): 2741-2776.

Cortner H. J. (2000) Making Science Relevant to Environmental Policy. Environmental Science or Policy 3(1): 21-30. 
Cvetkovich G. and Nakayachi K. (2007) Trust in a High-Concern Risk Controversy: A Comparison of Three Concepts. Journal of Risk Research 10(2): 223-237.

Dunlop C. A. (2009) Policy Transfer as Learning: Capturing Variation in What Decision-Makers Learn from Epistemic Communities. Policy Studies 30(3): 289-311.

Gianos P. L. (1974) Scientists as Policy Advisers: The Context of Influence. The Western Political Quarterly 27(3): 429-456.

Gough C. and Shackley S. (2001) The Respectable Politics of Climate Change: The Epistemic Communities and NGOs. International Affairs 77(2): 329-346.

Haas P. M. (1992a) Introduction: Epistemic Communities and International Policy Coordination. International Organization 14(1): 1-36.

(1992b) Banning Chlorofluorocarbons: Epistemic Community Efforts to Protect Stratospheric Ozone. International Organization 46(1): 187-224.

Heinrichs H. (2005) Advisory Systems in Pluralistic Knowledge Societies: A Criteria-Based Typology to Assess and Optimize Environmental Policy Advice. In Maasen S. and Weingart P. (eds.), Democratization of Expertise?: Exploring Novel Forms of Scientific Advice in Political Decision-Making. Dordrecht, The Netherlands: Springer, 41-61.

Hilgartner S. and Bosk C. L. (1988) The Rise and Fall of Social Problems: A Public Arenas Model. American Journal of Sociology 94(1): 53-78.

Holmes J. and Clark R. (2008) Enhancing The Use of Science in Environmental Policy-Making and Regulation. Environmental Science \& Policy 11(8): 702-711.

Hunt J. and Shackley S. (1999) Reconceiving Science and Policy: Academic, Fiducial and Bureaucratic Knowledge. Minerva 37(2): 141-164.

Intergovernmental Panel on Climate Change (IPCC) (2013) Climate Change 2013: The Physical Science Basis, http://www.ipcc.ch/report/ar5/wg1/. Accessed: 7 April 2015.

Jones B. D. and Baumgartner F. R. (2005a) A Model of Choice for Public Policy. Journal of Public Administration Research and Theory 15(3): 325-351.

(2005b) The Politics of Attention. Chicago: University of Chicago Press.

Keller A. C. (2009) Science in Environmental Policy: The Politics of Objective Advice. Cambridge: The MIT Press.

Kingdon J. W. (1995) Agendas, Alternatives, and Public Policies, 2nd ed. Boston: Little, Brown.

Kolbert E. (2006) Field Notes from a Catastrophe: Man, Nature, and Climate Change. New York: Bloomsbury, USA.

Leiserowitz A. (2006) Climate Change Risk Perception and Policy Preferences: The Role of Affect, Imagery, and Values. Climatic Change 77(1-2): 45-72.

Long J. S. (1997) Regression Models for Categorical and Limited Dependent Variables. Thousand Oaks, CA: Sage.

Martin B. and Richards E. (1995) Scientific Knowledge, Controversy, and Public DecisionMaking. In Jasanoff S., Markle G. E., Petersen J. C. and Pinch T. (eds.), Handbook of Science and Technology Studies. Thousand Oaks, CA: Sage, 506-526.

Matisoff D. C. (2008) The Adoption of State Climate Change Policies and Renewable Portfolio Standards: Regional Diffusion or Internal Determinants? Review of Policy Research 25(6): 527-546.

Mayhew D. R. (1974) Congress: The Electoral Connection. New Haven, CT: Yale University Press.

McCullagh P. and Nelder J. A. (1989) General Linear Models, 2nd ed. Boca Raton, FL: Chapman and Hall.

McKelvey R. D. and Zavoina W. (1975) A Statistical Model for The Analysis of Ordinal Level Dependent Variables. Journal of Mathematical Sociology 4(1): 103-120. 
Meijerink S. (2005) Understanding Policy Stability and Change: The Interplay of Advocacy Coalitions and Epistemic Communities, Windows of Opportunity, and Dutch Coastal Flooding Policy 1945-2003. Journal of European Public Policy 12(6): 1060-1077.

Montpetit E. (2011) Scientific Credibility, Disagreement, and Error Costs in 17 Biotechnology Policy Subsystems. Policy Studies Journal 39(3): 513-533.

Nakayachi K. and Cvetkovich G. (2010) Public Trust in Government Concerning Tobacco Control in Japan. Risk Analysis 30(1): 143-152.

Ostrom E. (2010) Polycentric Systems for Coping with Collective Action and Global Environmental Change. Global Environmental Change 20(4): 550-557.

Pearson G., Pringle S. M. and Thomas J. N. (1997) Scientists and The Public Understanding of Science. Public Understanding of Science 6(3): 279-289.

Pielke R. A. (2007) The Honest Broker: Making Sense of Science in Policy and Politics. Cambridge: Cambridge University Press.

Poliakoff E. and Webb T. L. (2007) What Factors Predict Scientists' Intentions to Participate in Public Engagement of Science Activities? Science Communication 29(2): 242-263.

Pralle S. B. (2009) Agenda-Setting and Climate Change. Environmental Politics 18(5): 781-799.

Robinson S. E., Liu X., Stoutenborough J. W. and Vedlitz A. (2013) Explaining Popular Trust in

The Department of Homeland Security. Journal of Public Administration Research and Theory 23(3): 713-733.

Rose R. (1991) What is Lesson-Drawing. Journal of Public Policy 11(1): 3-30.

Rosenbaum W. A. (2013) Science, Politics, and Policy at the EPA. In Vig N. J. and Kraft M. E. (eds.), Environmental Policy: New Directions for the Twenty-First Century, 8th ed. Washington, DC: CQ Press, 158-184.

Runhaar H. and van Nieuwaal K. (2010) Understanding the Use of Science in Decision-Making on Cockle Fisheries and Gas Mining in The Dutch Wadden Sea: Putting the Science-policy Interface in a Wider Perspective. Environmental Science \& Policy 13(3): 239-248.

Sabatier P. A. and Zafonte M. A. (2001) Policy Knowledge: Advocacy Organizations. In Smelser N. J. and Baltes P. B. (eds.), International Encyclopedia of the Social \& Behavioral Sciences vol. 17. Amsterdam: Elsevier, 11563-11568.

Sarewitz D. (2000) Science and Environmental Policy: An Excess of Objectivity. In Frodeman R. (ed.), Earth Matters: The Earth Sciences, Philosophy, and The Claims of Community. Upper Saddle River, NJ: Prentice-Hall, 79-98.

(2004) How Science Makes Environmental Controversies Worse. Environmental Science \& Policy 7(5): 385-403.

Schattschneider E. E. (1960) The Semisovereign People. New York: Holt, Rinehart, Winston.

Schooler D. Jr. (1971) Science, Scientists, and Public Policy. New York: The Free Press.

Selin H. and VanDeveer S. D. (2013) Global Climate Change: Beyond Kyoto. In Vig N. J. and Kraft M. E. (eds.), Environmental Policy: New Directions for the 21st Century, 8th ed. Washington, DC: CQ Press, 278-298.

Shackley S., Risbey J., Stone P. and Wynne B. (1999) Adjusting to Policy Expectations in Climate Change Modeling. Climatic Change 43(2): 413-454.

Steel B., List P., Lach D. and Shindler B. (2004) The Role of Scientists in The Environmental Policy Process: A Case Study from The American West. Environmental Science \& Policy 7(1): 1-13.

Stoutenborough J. W., Bromley-Trujillo R. and Vedlitz A. (2014a) Public Support for Climate Change Policy: Consistency in The Influence of Values and Attitudes over Time and Across Distinct Policy Alternatives. Review of Policy Research 31(6): 555-583.

Stoutenborough J. W., Fette R. N., Vedlitz A. and Goldsmith C. L. (2014b) Understanding the Communication of Climate Change Risk: Climate Scientists' Perspectives of Media Sources and Policy Makers. Risk, Hazards \& Crisis in Public Policy 5(4): 365-384. 
Stoutenborough J. W., Sturgess S. G. and Vedlitz A. (2013) Knowledge, Risk, and Policy Support: Public Perceptions of Nuclear Power. Energy Policy 62(11): 176-184.

True J. L., Jones B. D. and Baumgartner F. R. (2007) Punctuated-Equilibrium Theory: Explaining Stability and Change in Public Policymaking. In Sabatier P. A. (ed.), Theories of The Policy Process, 2nd ed. Boulder, CO: Westview, 155-188.

Turnhout E., Hisschemöller M. and Eijsackers H. (2008) Science in Wadden Sea Policy: From Accommodation to Advocacy. Environmental Science \& Policy 11(3): 227-239.

Ullmann-Margalit E. (2004) Trust, Distrust, and In Between. In Hardin R. (ed.), Distrust. New York: Russell Sage Foundation, 60-82.

van Buuren A. and Edelenbos J. (2004) Why is Joint Knowledge Production Such a Problem? Science and Public Policy 31(4): 289-299.

van Heerden I. and Bryan M. (2006) The Storm: What Went Wrong and Why During Hurricane Katrina - The Inside Story from One Louisiana Scientist. New York: Penguin.

Weible C. M. (2008) Expert-Based Information and Policy Subsystems: A Review and Synthesis. Policy Studies Journal 36(4): 615-635.

Weible C. M., Sabatier P. A., Jenkins-Smith H. C., Nohrstedt D., Henry A. D. and deLeon P. (2011) A Quarter Century of The Advocacy Coalition Framework: An Introduction to The Special Issue. Policy Studies Journal 39(3): 349-360.

Wildavsky A. B. (1979) The Art and Craft of Policy Analysis: Speaking Truth to Power. London: Macmillian.

Williams R. (2006) Generalized Ordered Logit/Partial Proportional Odds Models for Ordinal Dependent Variables. Stata Journal 6(1): 58-82.

\section{Appendix}

\section{Table A.1. Variable definitions}

\begin{tabular}{|c|c|c|}
\hline Variable & Question & Coding \\
\hline \multicolumn{3}{|c|}{ Dependent variables } \\
\hline Relationship & $\begin{array}{l}\text { How would you describe the working } \\
\text { relationship between climate scientists } \\
\text { and policy makers? (11-point scale } \\
\text { where } 0 \text { is No relationship and } 10 \text { is a } \\
\text { Very strong relationship) }\end{array}$ & $\begin{array}{l}0=0 \text { and } 1,1=2 \\
2=3,3=4,4=5 \\
5=6-10\end{array}$ \\
\hline Influence & $\begin{array}{l}\text { How much of a role do you think scientists } \\
\text { have played in transforming the climate } \\
\text { issue from being a scientific issue to a } \\
\text { public policy issue? (11-point scale } \\
\text { where } 0 \text { means No role and } 10 \text { means } \\
\text { Very important role) }\end{array}$ & $\begin{array}{l}0=0-4,1=5,2=6 \\
3=7,4=8,5=9 \\
\quad \text { and } 10\end{array}$ \\
\hline \multicolumn{3}{|c|}{ Independent variables } \\
\hline US mitigation & $\begin{array}{l}\text { To what degree is mitigation an option in } \\
\text { the US? Please choose one. We are } \\
\text { defining mitigation as it is defined by the } \\
\text { IPCC: human intervention to reduce the } \\
\text { sources of greenhouse gases. (11-point } \\
\text { scale, where } 0 \text { means Not at all an option } \\
\text { and } 10 \text { means Very much an option) }\end{array}$ & $\begin{array}{c}0=0 \text { and } 1,1=2 \text { and } \\
3,2=4-6,3=7 \text { and } \\
8,4=9 \text { and } 10\end{array}$ \\
\hline
\end{tabular}


Table A.1. Continued

\begin{tabular}{|c|c|c|}
\hline Variable & Question & Coding \\
\hline US adaptation & $\begin{array}{l}\text { How likely is it that the US will be able to } \\
\text { successfully adapt to the effects of global } \\
\text { climate change? Please choose one. We } \\
\text { are defining adaptation as it is defined } \\
\text { by the IPCC: adjustment in natural or } \\
\text { human systems in response to climate } \\
\text { change conditions or effects. (11-point } \\
\text { scale where } 0 \text { means Not at all likely and } \\
10 \text { means Very likely) }\end{array}$ & $\begin{array}{l}0=0 \text { and } 1,1=2 \text { and } \\
3,2=4-6,3=7 \text { and } \\
8,4=9 \text { and } 10\end{array}$ \\
\hline $\begin{array}{l}\text { Federal officials } \\
\text { (Trust) }\end{array}$ & $\begin{array}{l}\text { Using a scale of } 0-10, \text { where } 0 \text { means Not } \\
\text { at all competent, and } 10 \text { means } \\
\text { Completely competent, how would you } \\
\text { rate the competence of Congress to } \\
\text { make decisions about global climate } \\
\text { change? }\end{array}$ & $\begin{array}{l}0=0 \text { and } 1,1=2 \text { and } \\
3,2=4-6,3=7 \text { and } \\
8,4=9 \text { and } 10\end{array}$ \\
\hline Local officials (Trust) & $\begin{array}{l}\text { Using a scale of } 0-10, \text { where } 0 \text { means Not } \\
\text { at all competent, and } 10 \text { means } \\
\text { Completely competent, how would you } \\
\text { rate the competence of local officials to } \\
\text { make decisions about global climate } \\
\text { change? }\end{array}$ & $\begin{array}{l}0=0 \text { and } 1,1=2 \text { and } \\
\begin{array}{l}3,2=4-6,3=7 \text { and } \\
8,4=9 \text { and } 10\end{array}\end{array}$ \\
\hline State officials (Trust) & $\begin{array}{l}\text { Using a scale of } 0-10 \text {, where } 0 \text { means Not } \\
\text { at all competent, and } 10 \text { means } \\
\text { Completely competent, how would you } \\
\text { rate the competence of state officials to } \\
\text { make decisions about global climate } \\
\text { change? }\end{array}$ & $\begin{array}{l}0=0 \text { and } 1,1=2 \text { and } \\
3,2=4-6,3=7 \text { and } \\
8,4=9 \text { and } 10\end{array}$ \\
\hline $\begin{array}{l}\text { Federal officials } \\
\text { (Contact) }\end{array}$ & $\begin{array}{l}\text { What kinds of individuals or groups have } \\
\text { contacted you within the last } 5 \text { years for } \\
\text { information on global climate change? } \\
\text { Federal Officials }\end{array}$ & $\begin{array}{l}1=\text { Contacted, } 0=\text { Not } \\
\text { Contacted }\end{array}$ \\
\hline $\begin{array}{l}\text { State/local officials } \\
\text { (Contact) }\end{array}$ & $\begin{array}{l}\text { What kinds of individuals or groups have } \\
\text { contacted you within the last } 5 \text { years for } \\
\text { information on global climate change? } \\
\text { State/Local Officials }\end{array}$ & $\begin{array}{l}1=\text { Contacted, } 0=\text { Not } \\
\text { Contacted }\end{array}$ \\
\hline Public health & $\begin{array}{l}\text { On an } 11 \text {-point scale, where } 0 \text { is Not } \\
\text { relevant at all and } 10 \text { is Very relevant, } \\
\text { how relevant do you consider your } \\
\text { work to be for policy makers in public } \\
\text { health? }\end{array}$ & $\begin{array}{l}0=0 \text { and } 1,1=2 \text { and } \\
3,2=4-6,3=7 \text { and } \\
8,4=9 \text { and } 10\end{array}$ \\
\hline $\begin{array}{l}\text { Economic } \\
\text { development }\end{array}$ & $\begin{array}{l}\text { On an 11-point scale, where } 0 \text { is Not } \\
\text { relevant at all and } 10 \text { is Very relevant, } \\
\text { how relevant do you consider your } \\
\text { work to be for policy makers in } \\
\text { economic development? }\end{array}$ & $\begin{array}{l}0=0 \text { and } 1,1=2 \text { and } \\
3,2=4-6,3=7 \text { and } \\
8,4=9 \text { and } 10\end{array}$ \\
\hline
\end{tabular}


Table A.1. Continued

\begin{tabular}{|c|c|c|}
\hline Variable & Question & Coding \\
\hline Agriculture & $\begin{array}{l}\text { On an } 11 \text {-point scale, where } 0 \text { is Not } \\
\text { relevant at all and } 10 \text { is Very relevant, } \\
\text { how relevant do you consider your } \\
\text { work to be for policy makers in } \\
\text { agriculture? }\end{array}$ & $\begin{array}{l}0=0 \text { and } 1,1=2 \text { and } \\
\begin{array}{l}3,2=4-6,3=7 \text { and } \\
8,4=9 \text { and } 10\end{array}\end{array}$ \\
\hline Land use & $\begin{array}{l}\text { On an 11-point scale, where } 0 \text { is Not } \\
\text { relevant at all and } 10 \text { is Very relevant, } \\
\text { how relevant do you consider your } \\
\text { work to be for policy makers in land } \\
\text { use? Please choose only one. }\end{array}$ & $\begin{array}{l}0=0 \text { and } 1,1=2 \text { and } \\
3,2=4-6,3=7 \text { and } \\
8,4=9 \text { and } 10\end{array}$ \\
\hline Federal agency & $\begin{array}{l}\text { In which one of the following types of } \\
\text { organizations have you primarily } \\
\text { worked? Federal Agency }\end{array}$ & $\begin{array}{c}1=\text { Federal Agency, } \\
\text { ) }=\text { All Others }\end{array}$ \\
\hline Government lab & $\begin{array}{l}\text { In which one of the following types of } \\
\text { organizations have you primarily } \\
\text { worked? Government Lab }\end{array}$ & $\begin{array}{c}1=\text { Government Lab } \\
0=\text { All Others }\end{array}$ \\
\hline University & $\begin{array}{l}\text { In which one of the following types of } \\
\text { organizations have you primarily } \\
\text { worked? University Setting }\end{array}$ & $\begin{array}{c}1=\text { University Setting } \\
0=\text { All Others }\end{array}$ \\
\hline Field of study & $\begin{array}{l}\text { In which one of the following fields is most } \\
\text { of your academic training? Mark which } \\
\text { field(s) apply best: Math; Physics; } \\
\text { Atmospheric Physics; Oceanography; } \\
\text { Engineering; Ecology; Social Sciences; } \\
\text { Geography/Forestry; Chemistry. }\end{array}$ & $\begin{array}{l}\text { Each variable coded } \\
\qquad 0=\text { No, and } 1=\text { Yes }\end{array}$ \\
\hline Liberal & $\begin{array}{l}\text { Which of the following categories best } \\
\text { describes your political views? Would } \\
\text { you say that you are: Strongly Liberal, } \\
\text { Liberal, Slightly Liberal, Middle of the } \\
\text { Road, Slightly Conservative, } \\
\text { Conservative, Strongly Conservative. }\end{array}$ & $\begin{array}{l}1 \text { = Strongly Liberal, } \\
\text { Liberal, Slightly } \\
\text { Liberal, } 0=\text { All } \\
\text { Others }\end{array}$ \\
\hline Income & $\begin{array}{l}\text { What was the estimated annual income for } \\
\text { your household for 2003? }\end{array}$ & Reported Income \\
\hline Female & $\begin{array}{l}\text { As part of the survey, we are required to } \\
\text { ask, are you male or female? }\end{array}$ & $1=$ Female, $0=$ Male \\
\hline Age & How old are you? & Reported Age \\
\hline White & $\begin{array}{l}\text { From the following options, do you } \\
\text { consider yourself to be: Black or African } \\
\text { American, White, Asian, American } \\
\text { Indian, Native Hawaiian or other } \\
\text { Pacific Islander, Other? }\end{array}$ & $\begin{array}{l}1=\text { White, } 0=\text { All } \\
\text { Others }\end{array}$ \\
\hline
\end{tabular}

